\title{
Mitochondrial DNA Markers for PCR-Based Phylogenetic Analysis of Ark Shells
}

\author{
Tomomi Tanaka ${ }^{1,2}$, Futoshi Aranishi, ${ }^{1,2}$ \\ ${ }^{1}$ United Graduate School of Agricultural Sciences, Tottori University, Tottori, Japan \\ ${ }^{2}$ Coastal Lagoon Research Center, Shimane University, Matsue, Japan \\ Email: aranishi@soc.shimane-u.ac.jp
}

Received July 29, 2013; revised August 31, 2013; accepted September 12, 2013

Copyright (C) 2013 Tomomi Tanaka, Futoshi Aranishi. This is an open access article distributed under the Creative Commons Attribution License, which permits unrestricted use, distribution, and reproduction in any medium, provided the original work is properly cited.

\begin{abstract}
Arcidae species are commercially important bivalves in Japan and are commonly referred to as bloody ark due to their red blood. They have thick shells with distinct radiating ribs, and the numbers of these ribs are important morphological features for species discrimination. However, some Arcidae species are morphologically indistinguishable, with a similar number of the ribs in adults and deficient rib formation, particularly among juveniles. Thus, we developed a reliable molecular marker to genetically discriminate between 7 Arcidae species belonging to Scapharca, Anadara, and Tegillarca based on species-specific polymorphic segments of mitochondrial DNA. PCR amplification of partial COI, 16S rRNA, 12S rRNA, and Cyt $b$ genes was performed on 7 species using 8 primer sets. Only the set of Scapharca-specific forward primer and universal reverse primer for the partial COI gene successfully yielded single PCR products from all 7 species examined. Thus, nucleotide sequences of 481 bp portion of these PCR products were determined, and the degrees of nucleotide substitutions ranged from $0.4 \%$ between S. broughtonii and T. granosa to $20.2 \%$ between $S$. satowi and $A$. antiquata. In addition, a phylogenetic tree showed significant differences between 7 species, with higher bootstrap support than 69 .
\end{abstract}

Keywords: Ark Shell; Arcidae; Mitochondrial DNA; COI Gene; Phylogenetic Analysis

\section{Introduction}

Ark shells are a group of bivalves, in which red blood cells circulate through open blood-vascular systems, and hemoglobin pigment in both blood and tissue cells colors the body red [1]. Approximately 200 species of ark shells have been classified into the family Arcidae [2] and widely distributed globally in shallow tropical and temperate seas [3]. Arcidae is characterized by several derived characters including the duplivincular ligament, taxodont dentition, and shell microstructures consisting of outer crossed lamellar and inner complex crossed lamellar layers [4]. Many Arcidae species have considerable commercial value. In particular, Scapharca, Anadara, and Tegillarca have been actively collected for food throughout Asia [5]. In Japan, Scapharca broughtonii, S. satowi, S. kagoshimensis, S. inaequivalvis, S. globosa ursus, Anadara antiquate, and Tegillarca granosa are consumed by humans (Figure 1). Ark shells vary in size and are mostly elongate or squarish in shape. Shell surfaces are sculptured by radial ribs and covered with thick velvety periostracum [6]. These morphological features are important indicator of species identification, although the radial ribs are often similar between species (Table 1). Hence, morphologically identification of sympatrically related species is difficult, because their radial ribs are similar in number and change with maturity. Hence, genetic markers are required for accurate ark shells identification.

The use of molecular techniques to analyze relationships between species and populations has become widespread, and nucleotide sequence variations in the mitochondrial DNA (mtDNA) offer a powerful tool in molecular phylogenetics of marine organisms [7]. MtDNA markers have been widely used for discrimination of closely related species [8] and also for analyses of population genetic structure [9], however, there are few reports on the genetic studies of Arcidae. Such genetic data are of particular interest because Arcidae may reveal molecular evidence of gene flow or genetic isolation, which is undetectable using traditional morphological studies. In this study, genetic differences in the mtDNA cytochrome $c$ 


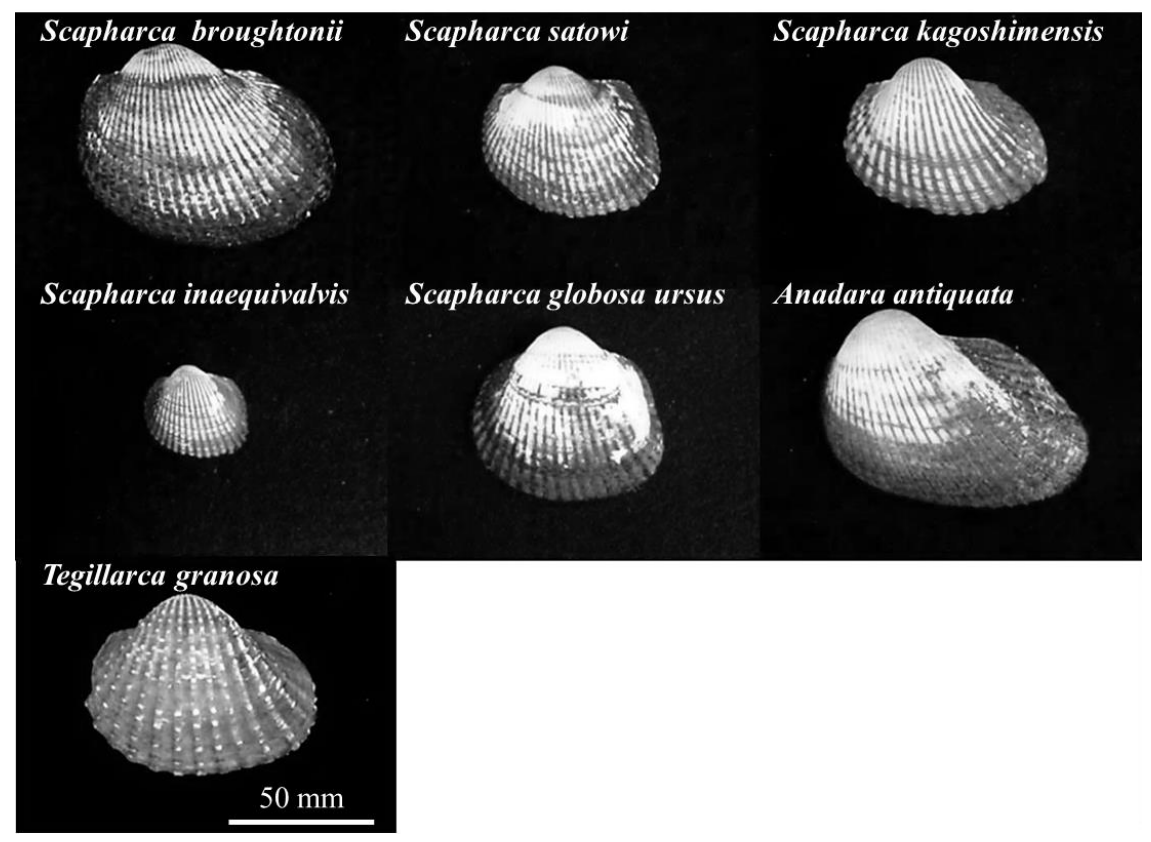

Figure 1. Photos of left valves of 7 Arcidae species.

Table 1. Morphological and geographical characterization of 7 Arcidae species based on Okutani [6] and sample profiles in this study.

\begin{tabular}{|c|c|c|c|c|c|c|c|}
\hline \multirow[t]{2}{*}{ Species } & \multirow[t]{2}{*}{$\begin{array}{l}\text { Approximate number } \\
\text { of radial ribs }\end{array}$} & \multirow[t]{2}{*}{$\begin{array}{l}\text { Size of adult } \\
\text { individual }\end{array}$} & \multirow[t]{2}{*}{ Distribution in Japan } & \multirow[t]{2}{*}{ Collection Site } & \multicolumn{3}{|c|}{ Shell } \\
\hline & & & & & SL (mm) & $\mathrm{SH}(\mathrm{mm})$ & $\mathrm{SW}(\mathrm{mm})$ \\
\hline Scapharca broughtonii & 42 & Large & Southern Hokkaido to Kyushu & Kagawa & 72.94 & 56.05 & 41.80 \\
\hline Scapharca satowi & 38 & Medium & Boso Peninsula to Kyushu & Shimane & 66.71 & 47.23 & 44.73 \\
\hline Scapharca kagoshimensis & 32 & Medium & Tokyo Bay to Kyushu & Saga & 35.71 & 28.01 & 29.20 \\
\hline Scapharca inaequivalvis & 32 & Medium & Boso Peninsula to Kyushu & Oita & 11.48 & 10.29 & 6.55 \\
\hline Scapharca globosa ursus & 34 & Medium & Ariake Sea and Omura Bay & Kumamoto & 28.78 & 24.92 & 18.55 \\
\hline Anadara antiquata & 38 & Medium & Okinawa & Okinawa & 62.13 & 46.12 & 41.72 \\
\hline Tegillarca granosa & 20 & Medium & Ise Bay to Kyushu & Saga & 44.60 & 34.91 & 30.39 \\
\hline
\end{tabular}

oxidase subunit I (COI), 16S ribosomal RNA (16S rRNA), cytochrome $b$ (Cyt $b$ ), and 12S ribosomal RNA (12S rRNA) genes between Scapharca, Anadara, and Tegillarca species were investigated using PCR amplification and subsequent sequence analysis to develop markers that discriminate between Arcidae species in Japan.

\section{Materials and Methods}

\subsection{Samples}

A total of 32 specimens were collected from May 2008 to November 2009, and their shell characteristics were recorded (Table 1). Adductor muscle was obtained from each specimen and immediately stored at $-20^{\circ} \mathrm{C}$ until DNA extraction.

\subsection{DNA Extraction}

High quality total genomic DNA was prepared from small scraps of frozen adductor muscle according to the modified urea-SDS-proteinase K method [10-12]. Samples were incubated in the extraction buffer $(10 \mathrm{mM}$ Tris$\mathrm{HCl}, \mathrm{pH} 7.5,20 \mathrm{mM}$ EDTA, pH 8.0, 1\% SDS, and $4 \mathrm{M}$ urea) containing $25 \mu \mathrm{g}$ proteinase $\mathrm{K}$ at $55^{\circ} \mathrm{C}$ and $5 \mathrm{M}$ $\mathrm{NaCl}$ was then added and mixed. DNA was isolated with phenol-chloroform-isoamyl alcohol and subsequent chloroform-isoamyl alcohol followed by precipitation with ethanol. DNA pellets were washed with ethanol, dried, and resuspended in 10T0.1E (10 mM Tris- $\mathrm{HCl}, \mathrm{pH} 7.5,0.1$ mM EDTA, $\mathrm{pH} 8.0$ ).

\subsection{PCR Amplification}

PCR amplification of the mtDNA regions was performed in GoTaq Green PCR Master Mix (Promega) containing $2 \mathrm{mM} \mathrm{MgCl} 2,0.5 \mu \mathrm{M}$ each primer listed in Table 2, and template DNA in a Techgene thermal cycler (Techne). PCR protocol consisted of an initial denaturation at $95^{\circ} \mathrm{C}$ 
Table 2. List of primer sequences.

\begin{tabular}{|c|c|c|c|c|}
\hline \multicolumn{2}{|c|}{ Primer set } & Primer sequence (5' to $\left.3^{\prime}\right)$ & Annealing temperature $\left({ }^{\circ} \mathrm{C}\right)$ & Reference \\
\hline COI-1 & $\begin{array}{l}\text { LCO1490 } \\
\text { HCO } 2198\end{array}$ & $\begin{array}{l}\text { GGT CAA CAA ATC ATA AAG ATA TTG G } \\
\text { TAA ACT TCA GGG TGA CCA AAA AAT CA }\end{array}$ & 52 & Folmer et al. [13] \\
\hline COI-2 & & $\begin{array}{l}\text { ATY GGN GGN TTY GGN AAY TG } \\
\text { ATN GCR AAY TTY GGN TC }\end{array}$ & 48 & Matsumoto and Hayami [14] \\
\hline COI-3 & $\begin{array}{l}\text { CGCIF } \\
\text { CGCIR }\end{array}$ & $\begin{array}{l}\text { ATT GGG GGG TTT GGT AAC TG } \\
\text { ATT GTA AAC AAA GCA CCC AT }\end{array}$ & 56 & Iidzuka Unpublished \\
\hline COI-4 & $\begin{array}{c}\mathrm{L} \\
\mathrm{HCO} 2198\end{array}$ & $\begin{array}{c}\text { GGT GTG TGT TTA AGA TTT CAC A } \\
\text { TAA ACT TCA GGG TGA CCA AAA AAT CA }\end{array}$ & 50 & $\begin{array}{l}\text { Lee and Kim [2] } \\
\text { Folmer et al. [13] }\end{array}$ \\
\hline $16 \mathrm{~S}-1$ & $\begin{array}{l}16 \mathrm{Sar} \\
16 \mathrm{Sbr}\end{array}$ & $\begin{array}{l}\text { CGC CTG TTT AAC AAA AAC AT } \\
\text { CCG GTC TGA ACT CAG ATC ATG T }\end{array}$ & 50 & Pulmbi et al. [15] \\
\hline $16 \mathrm{~S}-2$ & $\begin{array}{l}16 \mathrm{Sar} \\
16 \mathrm{Sbr}\end{array}$ & $\begin{array}{l}\text { CGC CTG TTT ATC AAA AAC AT } \\
\text { CCG GTC TGA ACT CAG ATC ACG T }\end{array}$ & 54 & Kessing et al. [16] \\
\hline Cytb-1 & $\begin{array}{l}\text { UCYTB151F } \\
\text { UCYTB272R }\end{array}$ & $\begin{array}{l}\text { TGT GGR GCN ACY GTW ATY ACT AA } \\
\text { GCR AAN AGR AAR TAC CAY TC }\end{array}$ & 48 & Merritt et al. [17] \\
\hline $12 \mathrm{~S}-1$ & $\begin{array}{l}\text { SSU-1 } \\
\text { SSU-2 }\end{array}$ & $\begin{array}{l}\text { GTG GAT CCA TTA GAT ACC C } \\
\text { ACT GGT ACC TTG TTA CGA CTT }\end{array}$ & 45 & Berschick [18] \\
\hline
\end{tabular}

for $2 \mathrm{~min}$, followed by 40 cycles of $10 \mathrm{sec}$ at $95^{\circ} \mathrm{C}, 20$ $\mathrm{sec}$ at annealing temperature listed in Table 2, and $40 \mathrm{sec}$ at $72^{\circ} \mathrm{C}$, and a final extension at $72^{\circ} \mathrm{C}$ for $5 \mathrm{~min}$. PCR products were analyzed using a DNA-1000 Reagent Kit (Shimadzu) containing a SYBR Gold Nucleic Acid Gel Stain (Invitrogen) in a MCE-202 MultiNA microchip electrophoresis system (Shimadzu).

\subsection{Phylogenetic Analysis}

Nucleotide sequencing of double strands of PCR product was accomplished using a BigDye Terminator version 3.1 Cycle Sequencing Kit (Applied Biosystems) with an automated 3730xl DNA Analyzer (Applied Biosystems). Nucleotide sequences of PCR products were aligned using CLUSTAL W [19] in MEGA version 5.5 [20] and deposited in GenBank (Scapharca broughtonii, AB690346; S. satowi, AB690347; S. kagoshimensis, AB690348; S. inaequivalvis, AB690349; S. globosa ursus, AB690350; Anadara antiquata, AB690351; and Tegillarca granosa, AB690352). A neighbor-joining tree with bootstrap analysis was constructed from 10,000 replicates based on the Kimura 2-parameter distance [21] using Cucullaea labiata (AB050892) and Barbatia fusca (AB050899) as outgroups.

\section{Results}

PCR tests were performed using 8 primer pairs to verify useful regions of the mtDNA for the phylogenetic analysis of 7 Arcidae species (Table 3).

Firstly, a universal primer pair COI-1 developed for PCR amplification of the mtDNA COI gene was examined. This primer pair amplified the mtDNA COI gene from 4 Arcidae species such as S. broughtonii, S. globosa ursus, A. antiquata, and T. granosa. Secondly, primer pairs COI-2 and COI-3 developed for PCR amplification of the bivalve the mtDNA COI gene were examined. Neither of these primer pairs amplified the mtDNA COI gene from 7 Arcidae species. Thirdly, a unique primer pair COI-4 developed for PCR amplification of Scapharca mtDNA COI gene was examined. The forward primer of COI-4 was designed as a nested PCR primer inside of the forward primer of the COI-1 [2]. This primer pair successfully amplified the mtDNA COI gene from 7 Arcidae species (Figure 2). Finally, universal primer pairs developed for PCR amplification of the mtDNA 16S rRNA, 12S rRNA, and Cyt $b$ genes were examined. The primer pairs of $16 \mathrm{~S}-1,16 \mathrm{~S}-2$, and Cyt-1 did not consistently amplify the respective genes from 7 Arcidae species, though a small amount of the PCR product was obtained from S. kagoshimensis by Cyt-1. A fragment of approximately $630 \mathrm{bp}$ was amplified from the mtDNA COI gene in all 7 Arcidae species using the unique primer pair COI-4, and a 481 bp portion of complementary nucleotide sequence was obtained after correction and alignment. The average base composition of these sequences was calculated to be $\mathrm{A}-25.10 \%$, $\mathrm{T}-$ $37.84 \%, \mathrm{C}-15.95 \%$, and $\mathrm{G}-21.12 \%$. Consistent with the known composition of mtDNA, this base composition was biased towards adenine and thymine (62.94\%). Alignment of the nucleotide sequences of the mtDNA COI gene of 7 Arcidae species revealed a relatively high level of variability, and 111 variable sites were determined from a total of 481 sites. Of 111 variable sites, there were 73 transitions and 45 transversions, and neither insertion nor deletion. In addition, 39 variable sites at the first or second codon positions occurred 31 nonsynonymous amino acid substitutions (Table 4). The lowest and highest degrees of nucleotide sequence substitution were calculated to be $0.4 \%$ between $S$. broughtonii and T. granosa and $20.2 \%$ between S. satowi and $A$. antiquata, respectively (Table 5). Phylogenetic analysis using Cucullaea labiata and Barbatia fusca as outgroups 
Table 3. PCR amplification of 7 Arcidae species.

\begin{tabular}{|c|c|c|c|c|c|c|c|c|}
\hline \multirow[t]{3}{*}{ Species } & \multicolumn{8}{|c|}{ MtDNA } \\
\hline & \multicolumn{4}{|c|}{$\mathrm{COI}$} & \multicolumn{2}{|c|}{ 16S rRNA } & \multirow{2}{*}{$\begin{array}{c}\text { Cyt } b \\
\text { Cytb-1 }\end{array}$} & \multirow{2}{*}{$\frac{12 \mathrm{~S} \text { rRNA }}{12 \mathrm{~S}-1}$} \\
\hline & COI-1 & COI-2 & COI-3 & COI-4 & $16 \mathrm{~S}-1$ & $16 \mathrm{~S}-2$ & & \\
\hline Scapharca broughtonii & o & $x$ & $x$ & o & $x$ & $x$ & $x$ & \\
\hline Scapharca satowi & $\times$ & $x$ & $\times$ & o & & & & \\
\hline Scapharca kagoshimensis & $\times$ & $\times$ & $\times$ & o & $\times$ & $\times$ & $\Delta$ & $\times$ \\
\hline Scapharca inaequivalvis & $x$ & $x$ & $x$ & ○ & & & & \\
\hline Scapharca globosa ursus & ० & $x$ & $\times$ & ○ & $\times$ & $\times$ & $x$ & \\
\hline Tegillarca granosa & ○ & $\times$ & $\times$ & ○ & $\times$ & $\times$ & $\times$ & \\
\hline
\end{tabular}

Open circle, open triangle, cross mark, and blank represent amplification of all specimens, amplification of a part of specimens, no amplification, and not tested, respectively. Primers are listed in Table 2.
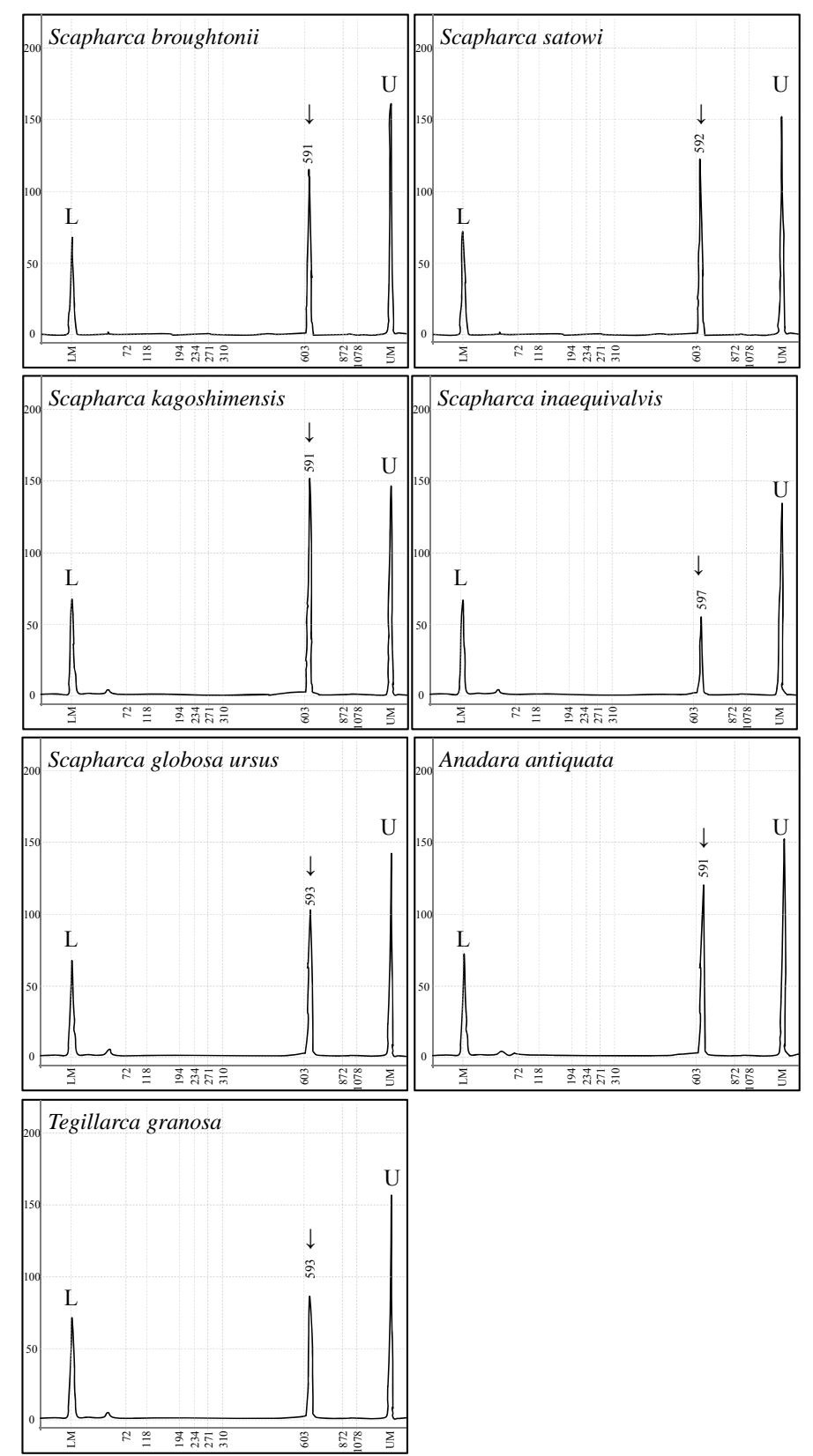

Figure 2. Electropherograms for PCR amplification of the mtDNA COI gene from 7 Arcidae species. L, lower marker; U, upper marker; arrow, PCR product. 


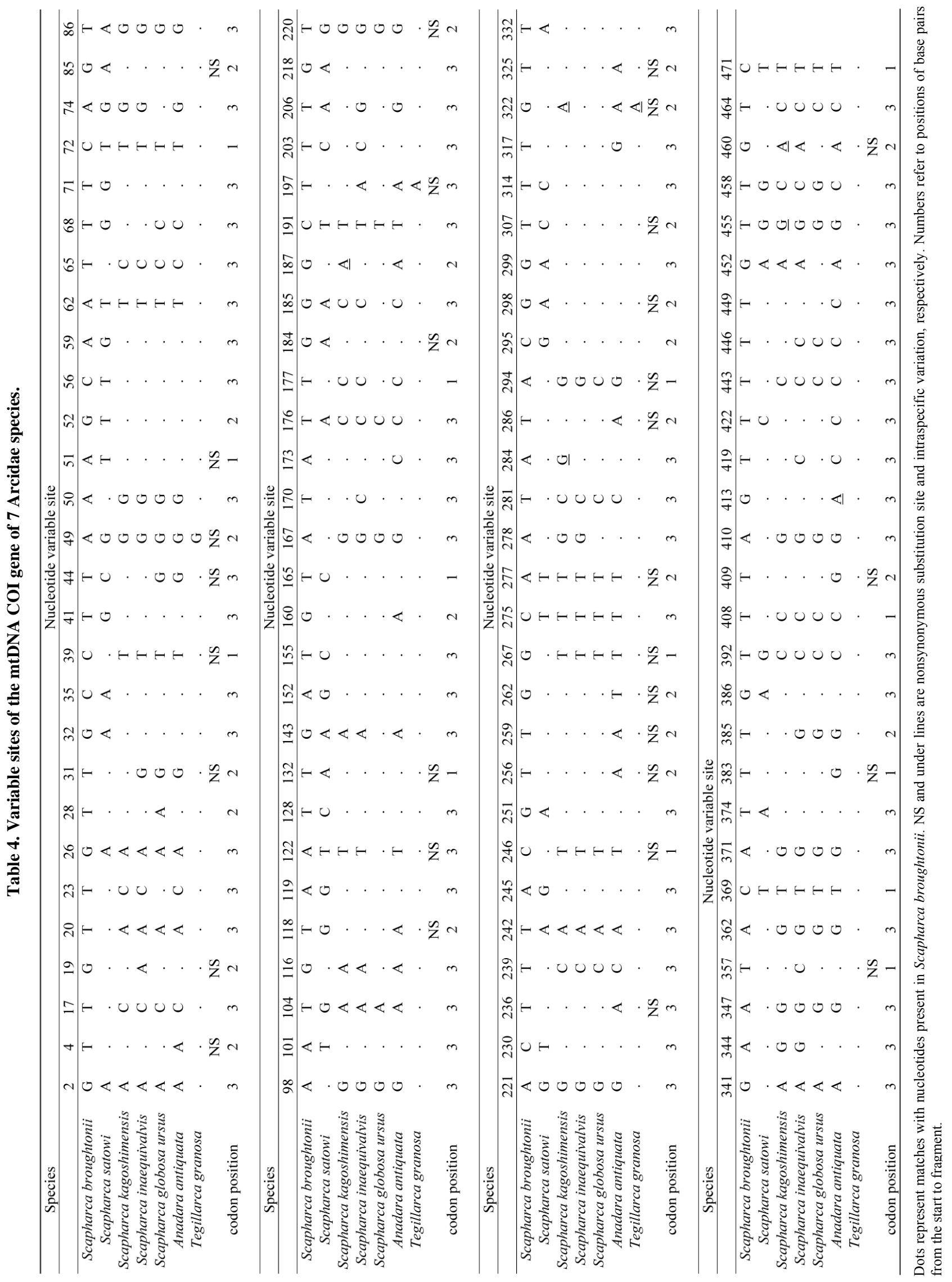


Table 5. Pairwise sequence divergences of the mtDNA COI gene of 7 Arcidae species.

\begin{tabular}{ccccccccc}
\hline \multicolumn{1}{c}{ Species } & \multicolumn{7}{c}{ Nucleotides } \\
\hline & & 1 & 2 & 3 & 4 & 5 & 6 & 7 \\
\hline 1 & Scapharca broughtonii & & 0.135 & 0.112 & 0.139 & 0.106 & 0.172 & 0.004 \\
2 & Scapharca satowi & 59 & & 0.165 & 0.176 & 0.162 & 0.202 & 0.135 \\
3 & Scapharca kagoshimensis & 49 & 70 & & 0.032 & 0.043 & 0.065 & 0.112 \\
4 & Scapharca inaequivalvis & 60 & 74 & 15 & & 0.045 & 0.054 & 0.134 \\
5 & Scapharca globosa ursus & 47 & 69 & 20 & 21 & & 0.070 & 0.106 \\
6 & Anadara antiquata & 73 & 84 & 30 & 25 & 32 & & 0.166 \\
7 & Tegillarca granosa & 2 & 59 & 49 & 58 & 47 & 71 & \\
\hline
\end{tabular}

Above and below diagonal indicate mean distance values calculated by the Kimura's two-parameter distance method and number of nucleotide substitutions, respectively.

suggested that 7 Arcidae species formed a monophyletic clade, which was supported by higher bootstrap values than 69. These analyses additionally indicated that $A$. antiquata and T. granosa could be the sister group to Scapharca species (Figure 3).

\section{Discussion}

In recent years, bivalve resources have been threatened by overfishing or ecological changes, resulting in decreases in wild stocks in Japan [22]. In an effort to promote stock restoration, bivalve seeds were imported and released into coastal waters for farming, and seeds of many mollusk species including $S$. broughtonii and $S$. subcrenata were mixed with clam seeds and released into fishing areas of Japan [23].

Despite the commercial importance of Arcidae in Japan, to date little is known about its genetic characteristics and phylogenetic relationships in the native range [24]. Recent developments of DNA markers and genetic identification keys have helped to resolve questions surrounding bivalve taxonomic profiles. Molecular diagnostic markers were specifically developed to identify $S$. broughtonii in Korea and China [25,26], but these remain unavailable in Japan. In addition, molecular diagnostic markers for discriminating sympatrically distributed, closely related species belonging to Arcidae was also unavailable. In this study, we developed a reliable molecular diagnostic marker, which genetically discriminates between 7 Arcidae species belonging to Scapharca, Anadara, and Tegillarca based on the species-specific polymorphic segments of mtDNA COI gene.

Lee and Kim [2] reported genetic differentiation among S. broughtonii, S. satowi, and S. subcrenata in Korea based on a $599 \mathrm{bp}$ portion of the mtDNA COI gene. The number and degree of nucleotide sequence variations among these 3 Scapharca species ranged from $27 \%$ to $48 \%$ and from $4.7 \%$ to $12.4 \%$, respectively. Those among the same Scapharca species in Japan, however, ranged from $49 \%$ to $70 \%$ and from $11.2 \%$ to $16.5 \%$, respectively, despite the shorter $481 \mathrm{bp}$ portion of the corresponding

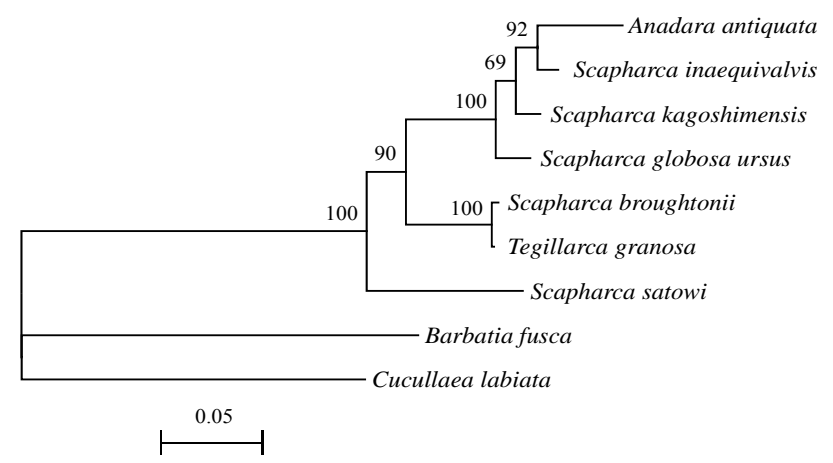

Figure 3. Neighbor-joining tree of 7 Arcidae species with Barbatia fusca and Cucullaea labiata as outgroup inferred from the mtDNA COI gene. Bootstrap values higher than 50 are shown at nodes.

the mtDNA COI gene (Table 5). These results suggest that genetic differentiation among S. broughtonii, S. satowi, and S. subcrenata may have progressed in Japan more than in Korea.

Matsumoto and Hayami [24] reported genetic relationship among S. broughtonii, S. satowi, S. subcrenata, Diluvarca tricenicosta, and Tegillarca granosa in Japan, A. antiquata in Philippine and T. nodifera in China based on deduced 302 amino acid sequences of the mtDNA COI gene. The neighbor-joining tree formed a monophyletic clade with Scapharca, Diluvarca, Anadara, and Tegillarca with high bootstrap support.

In the present study, Figure $\mathbf{3}$ showed a monophyletic clade including Scapharca, Anadara, and Tegillarca, using a neighbor-joining tree. These nucleotide and amino acid sequences of the mtDNA COI gene indicated a monophyletic clade of closely related genera that belong to Anadarinae. In conclusion, the mtDNA COI gene was verified as a sensitive DNA marker for species identification of Arcidae species. Although DNA sequencing is undoubtedly the most powerful approach, it is costly and time-consuming. Single nucleotide polymorphisms (SNPs) genotyping has been extensively used for species identification, even in bivalves [27]. We accordingly determined several sites containing species-specific SNPs, and 
developed a simple and easily accessible SNPs genotyping method to identify Arcidae species using speciesspecific PCR amplification of the mtDNA COI gene.

\section{Acknowledgements}

We thank to Dr. Ayako Yamakawa from Okinawa International University, Dr. Keiko Yamaguchi from Shimane University and Ms. Kumiko Tsuru from Oita Prefectural Agriculture, Forestry and Fisheries Research Center for providing the samples. This research was supported in part by Grant-in-Aid for JSPS Fellows Grant Number 24-2801 to Tomomi Tanaka as JSPS Research Fellow DC2, and by grants from the Agriculture, Forestry and Fisheries Council of Japan.

\section{REFERENCES}

[1] J. E. Morton, "Molluscs, an Introduction to Their Form and Function," Harper and Brothers, New York, 1960.

[2] S. Y. Lee and S. H. Kim, "Genetic Variation and Discrimination of Korean Arkshell Scapharca Species (Bivalvia, Arcoida) Based on Mitochondrial COI Gene Sequences and PCR-RFLP," Korean Journal of Genetics, Vol. 25, No. 4, 2003, pp. 309-315.

[3] Geological Survey, "Geological Survey Professional Paper Volume 1228," Government Printing Office, Washington DC, 1983.

[4] J.D. Taylor, J. Kennedy, M. Nei and S. Kumar, "The Shell Structure and Mineralogy of Bivalvia. Introduction. Nuculacea-Trigonacea," British Museum Natural History, London, 1969.

[5] Y. Feng, Q. Li, L. Kong and X. Zheng, "COI-Based DNA Barcoding of Arcoida Species (Bivalvia: Pteriomorphia) along the Coast of China," Molecular Ecology Resources, Vol. 11, No. 3, 2011, pp. 435-441. http://dx.doi.org/10.1111/j.1755-0998.2010.02975.x

[6] T. Okutani, "Class BIVALVIA/Subclass PTERIOMORPHIA/Orde ARCOIDA," In: T. Okutani, Ed., Marine Mollusks in Japan, Tokai University press, Kanagawa, 2001, pp. 845-855. (in Japanese)

[7] G. R. Carvalho and T. J. Pitcher, "Molecular Genetics in Fisheries," Chapman \& Hall, London, 1995. http://dx.doi.org/10.1007/978-94-011-1218-5

[8] Y. Iidzuka and F. Aranishi, "DNA Fingerprinting for Ostreidae Oysters in Kyushu," LAGUNA, Vol. 15, 2008, pp. 69-76. (in Japanese)

[9] T. D. Kocher, W. K. Thomas, A. Meyer, S. V. Edwards, S. Paabo, F. X. Villablanca and A. C. Wilson, "Dynamics of Mitochondrial DNA Evolution in Animals: Amplification and Sequencing with Conserved Primers," Proceedings of the National Academy of Sciences of the United States of America, Vol. 86, No. 16, 1989, pp. 6196-6200. http://dx.doi.org/10.1073/pnas.86.16.6196

[10] F. Aranishi and T. Okimoto, "Genetic Relationship between Cultured Populations of Pacific Oyster Revealed by RAPD Analysis," Journal of Applied Genetics, Vol.
45, No. 4, 2004, pp. 435-443.

[11] F. Aranishi and T. Okimoto, "Sequence Polymorphism in a Novel Noncoding Region of Pacific Oyster Mitochondrial DNA," Journal of Applied Genetics, Vol. 46, No. 2, 2005, pp. 201-206.

[12] F. Aranishi, "A Novel Mitochondrial Intergenic Spacer Reflecting Population Structure of Pacific Oyster," Journal of Applied Genetics, Vol. 47, No. 2, 2006, pp. 119123. http://dx.doi.org/10.1007/BF03194610

[13] O. Folmer, M. Black, W. Hoeh, R. Lutz and R. Vrijenhoek, "DNA Primers for Amplification of Mitochondrial Cytochrome $c$ Oxidase Subunit I from Diverse Metazoan Invertebrates," Molecular Marine Biology and Biotechnology, Vol. 3, No. 5, 1994, pp. 294-299.

[14] M. Matsumoto and I. Hayami, "Phylogenetic Analysis of the Family Pectinidae (Bivalvia) Based on Mitochondrial Cytochrome C Oxidase Subunit I," Journal of Molluscan Studies, Vol. 66, No. 4, 2000, pp. 477-488. http://dx.doi.org/10.1093/mollus/66.4.477

[15] S. R. Palumbi, A. P. Martin, W. O. McMillan, S. Romano, L. Stice and G. Grabowsky, "The Simple Fool's Guide to PCR," 2nd Edition, University of Hawaii, Honolulu, 1991.

[16] B. Kessing, H. Croom, A. Martin, C. McIntosh, W. O. McMillan and S. Palumbi, "The Simple Fool's Guide to PCR," Department of Zoology, University of Hawaii, Honolulu, 1989

[17] T. J. S. Merritt, L. Shi, M. C. Chase, M. A. Rex, R. J. Etter and J. M. Quattro, "Universal Cytochrome $b$ Primers Facilitate Intraspecific Studies in Molluscan Taxa," Molecular Marine Biology and Biotechnology, Vol. 7, No. 1, 1998, pp. 7-11.

[18] P. Berschick, "One Primer Pair Amplifies Small Subunit Ribosomal DNA from Mitochondria, Plastids and Bacteria," Biotechniques, Vol. 23, No. 3, 1997, pp. 494-498.

[19] J. D. Thompson, D. G. Higgins and T. J. Gibson, "CLUSTAL W: Improving the Sensitivity of Progressive Multiple Sequence Alignment through Sequence Weighting, Position-Specific Gap Penalties and Weight Matrix Choice," Nucleic Acids Research, Vol. 22, No. 22, 1994, pp. 4673-4680. http://dx.doi.org/10.1093/nar/22.22.4673

[20] K. Tamura, D. Peterson, N. Peterson, G. Stecher, M. Nei and S. Kumar, "MEGA5: Molecular Evolutionary Genetics Analysis Using Maximum Likelihood, Evolutionary Distance, and Maximum Parsimony Methods," Molecular Biology and Evolution, Vol. 28, No. 10, 2011, pp. 27312739. http://dx.doi.org/10.1093/nar/22.22.4673

[21] M. Kimura, "A Simple Method for Estimating Evolutionary Rates of Base Substitutions through Comparative Studies of Nucleotide Sequences," Journal of Molecular Evolution, Vol. 16, No. 2, 1980, pp. 111-120. http://dx.doi.org/10.1007/BF01731581

[22] Ministry of Agriculture, Forestry and Fisheries, "Annual Statistics of Fishery and Aquaculture Production," Association of Agriculture \& Forestry Statistics, Tokyo, 2009. (in Japanese)

[23] K. Okoshi, "Alien Species Introduced with Imported Clams: The Clam-Eating Moon Snail Euspira fortunei 
and Other Unintentionally Introduced Species," Japanese Journal of Benthology, Vol. 59, 2004, pp. 74-82. (in Japanese)

[24] M. Matsumoto and I. Hayami, "Molecular Phylogenetics and Taxonomic Characters of the Anadarinae (Bivalvia)," FOSSILS, Vol. 69, 2001, pp. 25-34. (in Japanese)

[25] M. J. Lee, J. W. Park, M. S. Yoo and Y. K. Hong, "Morphological Characteristics and Genetic Diversity Using the RAPD Technique in the Ark Shell, Scapharca broughtonii (Schrenck) from Korea and China," Journal of the Korean Fisheries Society, Vol. 30, No. 2, 1997, pp. 297-304.
[26] E. S. Cho, C. G. Jung, C. W. Kim and S. G. Sohn, "Development of Molecular Detection Marks Using PCRRFLP Technique for Arkshell (Scapharca broughtonii Schrenck)," Korean Journal of Life Science, Vol. 15, No. 6, 2005, pp. 879-883.

http://dx.doi.org/10.5352/JLS.2005.15.6.879

[27] H. Wang and X. Guo, "Identification of Crassostrea ariakensis and Related Oysters by Multiplex Species-Specific PCR," Journal of Shellfish Research, Vol. 27, No. 3, 2008, pp. 489-493.

http://dx.doi.org/10.5352/JLS.2005.15.6.879 